DE DE GRUYTER

OPEN

Polish Cartographical Review

Vol. 47, 2015, no. 1, pp. 63-72

DOI: $10.1515 / p c r-2015-0005$

TADEUSZ PASTUSIAK

Gdynia Maritime University

tadeusz.pastusiak@wp.pl

\title{
The problem of the availability of nautical charts and publications on the Northern Sea Route
}

\begin{abstract}
Statistical studies of marine accidents and unfortunate events in ice-covered areas in 1995-2004 and 2004-2011 showed a general lack of information from the area under the jurisdiction of the Russian Federation. The author's research for the period 2004-2011 showed a large number of unfortunate events caused by lack of adequate provision of nautical charts, shortage of accurate position systems on board vessels as well as weak technical condition of these vessels. The author examined the problem of navigation safety on the Northern Sea Route in terms of availability of the official nautical charts and publications.

The availability of official nautical publications supplied by global producers is more diverse and ambiguous than it is in case of nautical charts. Surprising is lack of Russian publications related to tides and unavailability of a guide for planning routes on Northern Sea Route issued by Russia in Russian and English languages.

Global producers of official charts and nautical publications do not provide full range of information and recommend vessels the use of the products supplied by Russia. These products are issued in Russian. This is a serious impediment to their use and thus introduces privilege of ships' crews who speak Russian.

Northern Sea Route leads through regions that are not sufficiently explored. The Northern Sea Route Administration recommends guiding ships only on designated routes marked on maps and described in nautical publications. The currently hydrographic work is focused on determining new routes according to the spatial distribution of the ice massifs during the navigation season. However, this does not solve the problem of a comprehensive exploration of the Russian Arctic regions for the purpose of safe navigation on the customized routes.
\end{abstract}

Keywords: Northern Sea Route, official sea charts, official nautical publications

\section{Introduction}

Shipping routes along the coast of the Russian Arctic were recognized progressively during the migration of the local population living in this region. In 1648 Semyon Dezhnev discovered possibility to move from Europe to the Far East. The first map of the Arctic Ocean passage from west to east was developed in the years 1691-1692. The first known case of the Northern Sea Route passage took place in the years 1878-1879. It just made polar explorer Nils Nordenskjöld on a small vessel Vega on behalf of Siberian merchants and industrialists as well as the King of Sweden. In the thirties of the twentieth century icebreaker Sibirjakov crossed Northern Sea Route within one navigation season (A.\&Cz. Centkiewiczowie 1959). The expansion of Trans-Siberian Railway was the first impulse for commercial shipping on the Northern Sea Route. Increased movement of vessels was observed since 1893. Initially shipping concerned only the eastern and western sections of the route. There was the most traffic in ports located on the $\mathrm{Ob}$ and Yenisei river. The movement of vessels on the entire route was observed since 1935 (T. Armstrong 1952).

During the Second World War, the movement of ships on the Northern Sea Route was related mainly to military supplies from Europe and from the United States to the Soviet Union. The activities of German warships in this region in 1941-1944 forced the complete suspension of military equipment deliveries only during the months of the polar summer of 1942. Directly after the end of World War II, a small number of ships and icebreakers, which held 
the Soviet Union, was not enough for transit voyages. However, in the years 1952-1953 vessels with hull of significant ice reinforcements that allow the vessels' self-navigating in one year old ice have been put into operation. In the sixties and seventies of the twentieth century, there was a rapid increase in traffic on the Northern Sea Route. A year-round voyages to Dudinka commenced in 1978. In the years 1988-1994, after the disintegration of the Soviet Union, there was a sudden reduction of traffic on this route, which lasted up to 2003. At that time there was a slow increase in traffic related to the development of the mining industry, oil and natural gas in Siberia. With a clear improvement of the ice conditions in the Russian Arctic appeared the concept of using the Northern Sea Route for the transport between ports in Europe and the Far East ports as an alternative to routes leading through the Suez Canal and the Panama Canal. Northwest Passage is not competitive with other transit routes. This is due to difficult ice conditions and very short period of navigation season. The analysis of climate change by the end of the twenty-first century indicate that cold pole will remain for decades, just north of Greenland, while global warming and favorable conditions for shipping will occur beginning from the coast of Russia (J.E. Walsh 2008, IPCC WG-1 2013). Another problem related to both Northwest Passage and Northern Sea Route is a high level of risk of entrapment of a vessel in the ice or hull damage and even loss of the vessel as well as the unpredictability of ice conditions as the main factor in the feasibility on a transit passage. For these reasons, the development prospects of maritime transport is seen in the Northern Sea Route and not in the North-West Passage.

Northern Sea Route runs along the coasts of the European and Asian parts of Russia, between the Novaya Zemlya and the Bering Strait (F. Peresypkin and A. Yakovlev 2008). It passes through the four seas of the Russian Arctic: Kara Sea, Laptev Sea, East Siberian Sea and Chukchi Sea. All these seas are located north of the Arctic Circle. Southern borders of these seas are the coast of the continent. The eastern and western boundaries form a group of islands: Novaya Zemlya, Severnaya Zemlya, New Siberian Islands and Wrangel Island (fig. 1). Nor- thern borders of these seas are determined by lines connecting the northern headland of archipelago (Kara Sea) or points defining the upper bend of continental shelf at the meridian of headland's that are most extended north of the archipelago (the Laptev Sea, East Siberian Sea and Chukchi Sea).

One can pass different routes through the Northern Sea Route depending on the season of year, occurring ice conditions, ice class of the vessel and the type of practiced navigation (transit or to a designated location). Routes leading along the Northern Sea Route may be divided generally on the adjacent to the land, away from the mainland and transarctic (N.D. Mulherin at all. 1994; N.D. Mulherin 1996; O.M. Johannessen at all. 2007; N. Marchenko 2012). Their overall spatial distribution is shown on figure 1.

There are two main difficulties for navigation on this multivariant route. On one hand there are narrow passages between the islands of the archipelagos (which separate particular seas) as well as between the islands and the mainland. On the other hand - the compact sea ice cover and the sea ice edge in the summer, often adjacent to the northern coasts of groups of islands, that reduces possibility of free circumnavigation around these archipelagos from the north. Such difficulties are in the vicinity of the Novaya Zemlya, Severnaya Zemlya, New-Siberian Islands, Wrangel Island and the Bering Strait.

Statistical studies of accidents and unfortunate events in the ice-covered regions in 1995-2004 revealed a lack of information from the area under the jurisdiction of the Russian Federation (T. Pastusiak 2011). Also no information was available about the prospects for development of fisheries. Author's own research on the period 2004-2011 revealed a large number of unfortunate events caused by lack of proper adequate provision for navigation (sea charts not up-to-dated) and the shortages of accurate positioning systems as well as poor technical condition of these vessels. Research for the period 2004-2011 revealed generally "blind spot" of information about events in the region of the Northern Sea Route. One may be concluded that the problems are similar to those in other regions around the North Pole, but either not conducted official statistics, or there is a lack of statistical information flow towards 


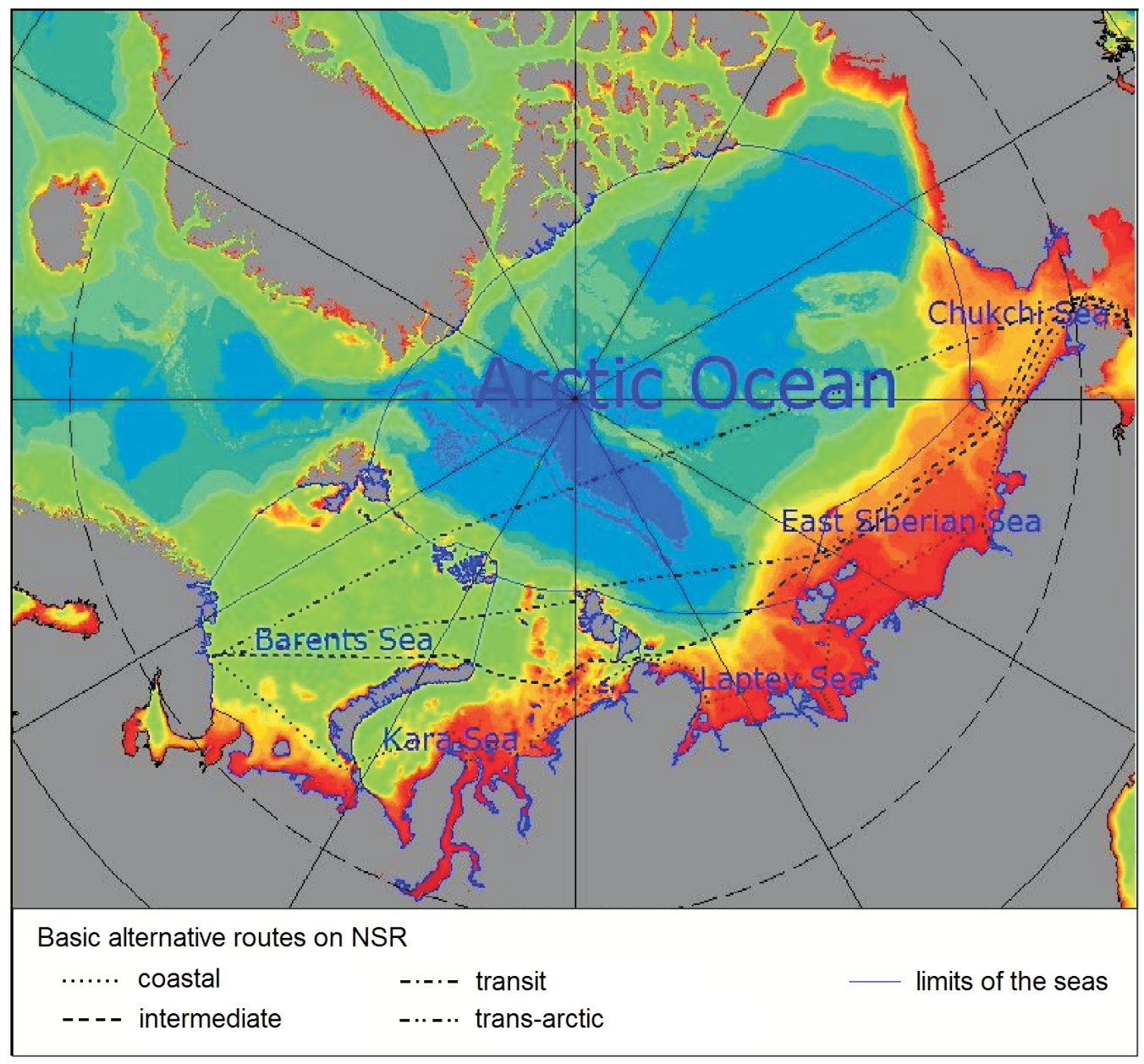

Fig. 1. Basic alternative routes on NSR (author's study based on ESIMO 2011/3 and N. Marchenko 2012)

the international community. This situation indicated the need to investigate the problem of safety of navigation in terms of the availability of information. So work paid attention to the availability of the official charts and nautical publications on the Northern Sea Route.

\section{Official nautical charts}

\subsection{Research method}

The official nautical charts have been adopted primarily as a basis for assessing the quality assurance of navigational information for the route in question. The scale of these charts was taken as a measure of the quality of their usability, that is, the completeness of the information and level of detail required, according to type of practiced navigation (T. Pastusiak 2009). It was assumed that on the open sea, away from the land and navigational hazards, a chart quality is less important, but it is particularly important in cases where the vessel has to get close to the shore or just such dangers. A detailed analysis of available navigation charts was carried out for such cases.

Although so far the most common on vessels are paper charts of the British Admiralty 
(UKHO 2011), however, is growing more and more importance of Electronic Chart Display and Information System ECDIS and Electronic Navigational Charts ENC. For this reason, it is pointed out, who has been designated as a provider of vector electronic charts for the area of the Northern Sea Route. This information was found on the website of the International Centre for ENCs (ic-enc.org). It has proved to be PRIMAR (www.primar.org). Particular attention was paid to the paper charts and vector electronic charts ENC supplied by Russia as the Northern Sea Route area runs solely along the coast of Russia (UNiO 2011). Twenty-three charts covering the area of the Northern Sea Route has been provided by Russia in 1992 (N.D. Mulherin 1996). In 1999, it was already available many Russian paper charts and 300 electronic charts which satisfactorily covered the region (C.L. Ragner 2000). The largest scale charts covering all or part of the selected sections of the Northern Sea Route along with the number of these charts are given in table 1.

\subsection{Analysis of the availability of official nautical charts for particular narrow passages}

The comparison (table 1) shows that the producer of electronic vector charts ENC for the area of the Northern Sea Route is only Russia (prefix number of international chart "RU"). The British Admiralty charts do not cover most of the route and the scale of existing charts is usually worse than provided by Russia. Very small scale of Russian maps for Yugorskiy Shar strait and especially for Matochkin Shar strait suggests that these straits are not intended by the Russian administration for ships navigating on the Northern Sea Route. For this reason, the author did not deal with them later in the article. Scales of available charts for the passages north of the consecutive archipelagos and on both sides of Wrangel Island meet the criteria for navigation along the coast (coastal navigation). From this fact, it is concluded that either of these passages are not in the center of shipping interests, or it is assumed that it is possible implement safe navigation away from the land.

\subsection{Discussion of results}

Paper charts and electronic charts provided by Directorate for Navigation \& Oceanography $\mathrm{UNiO}$ are made at larger scales than the international electronic charts provided by PRIMAR. The scale of available electronic charts provided by Directorate for Navigation \& Oceanography UNiO change proportionally to the width of passage and the distance to the shoreline as a danger (fig. 2). These observations confirm the suggestion of the British Admiralty (UKHO 2011), that local charts must be used in the regions where there are available more detailed local charts of the coastal State. This is connected with the necessity of access to the Russian nautical publications concerning symbols and abbreviations on Russian charts and regular acquisition of Russian "Notices to Mariners". Provisions concerning navigation on the Northern Sea Route (MMM 1990) clearly inform that the vessels sailing on the NSR should have the latest Russian nautical charts and publications with the relevant corrections.

\section{Nautical publications}

\subsection{Research method}

It was assumed that the maps contain $70-80 \%$ of marine navigational information about the region (M. Jurdziński 1989). The remaining 20-30\% of the information should be obtained by the navigator from the official nautical publications. Fundamental group of nautical publications available for the area of the Northern Sea Route are summarized in table 2. It was adopted the number of publications available in the thematic group and their total volume (number of pages) for particular global producers and for individual areas the Northern Sea Route to evaluate the quality of information.

\subsection{Analysis of official nautical publications available for selected thematic groups}

The total volume of the navigation information offered by Russia for the region of the Northern Sea Route (2614 pages) far exceeds the materials supplied by other agencies (United Kingdom Hydrographic Office UKHO - 1538 
Table 1. The largest scales of the official charts of selected producers for particular narrow passages of the Northern Sea Route (author's study based on ChartPilot 2010, PRIMAR 2011, UKHO 2011, UKHO 2012 and UNiO 2011)

\begin{tabular}{|c|c|c|c|c|}
\hline \multirow{2}{*}{ Narrow passage } & \multicolumn{4}{|c|}{$\begin{array}{l}\text { The largest scale of charts of the selected producer covering the area } \\
\text { (in parentheses the reference number of the map) }\end{array}$} \\
\hline & $\begin{array}{c}\text { UKHO } \\
\text { Paper charts }\end{array}$ & \begin{tabular}{|c|} 
UNiO \\
Paper charts \\
\end{tabular} & $\begin{array}{c}\text { ICENC } \rightarrow \\
\text { PRIMAR ENC }\left({ }^{*} .000\right)\end{array}$ & $\begin{array}{c}\text { UNiO } \\
\text { ENC }\left({ }^{*} .000\right) \\
\end{array}$ \\
\hline $\begin{array}{l}\text { Yugorskiy Shar Strait } \\
\text { Novaya Zemlya, } \\
\text { Barents Sea - Kara Sea }\end{array}$ & $\begin{array}{l}1: 90,000 \\
(2967)\end{array}$ & $\begin{array}{l}: 25,000 \\
(18316 \text { western, } \\
\text { narrow part), } \\
1: 50000 \\
\text { (15030 eastern, } \\
\text { larger part) } \\
\end{array}$ & $\begin{array}{l}1: 180,000 \\
\text { (RU3OPNJ9) }\end{array}$ & \begin{tabular}{|l|}
$1: 25,000$ \\
(CP5OSNT0 18316 \\
western, narrow part), \\
1:200,000 \\
(CP3OSNS0 eastern, \\
larger part) \\
\end{tabular} \\
\hline $\begin{array}{l}\text { Kara Gates Strait } \\
\text { Novaya Zemlya, } \\
\text { Barents Sea - Kara Sea }\end{array}$ & $\begin{array}{l}1: 90,000 \\
(2967)\end{array}$ & \begin{tabular}{|l}
$1: 100,000$ \\
$(13314$ whole), \\
$1: 50,000$ \\
$(15315,15317)$, \\
$1: 25,000$ \\
$(18314,18315)$ \\
\end{tabular} & $\begin{array}{l}\text { 1:180,000 } \\
\text { (RU3P0NJ9 whole), } \\
1: 45,000 \\
\text { (RU4P1NL0, } \\
\text { RU4P1NI0 northern } \\
\text { part) } \\
\end{array}$ & $\begin{array}{l}1: 90,000 \\
(\mathrm{CP} 30 \mathrm{SNQ})\end{array}$ \\
\hline $\begin{array}{l}\text { Matochkin Shar Strait } \\
\text { Novaya Zemlya, } \\
\text { Barents Sea - Kara Sea }\end{array}$ & $\begin{array}{l}1: 350,000 \\
(3182)\end{array}$ & $\begin{array}{l}1: 500,000 \\
(11116,11126)\end{array}$ & $\begin{array}{l}1: 700,000 \\
(\mathrm{RU} 2 \mathrm{P} 8 \mathrm{MH} 9)\end{array}$ & \begin{tabular}{|l|}
$1: 500,000$ \\
(CP2P5NE0, \\
CP2P8LT8) \\
\end{tabular} \\
\hline North of Novaya Zemlya & $\begin{array}{l}1: 350,000 \\
(3182)\end{array}$ & $1: 100,000(13215)$ & $\begin{array}{l}1: 700,000 \\
(\mathrm{RU} 2 \mathrm{P} 8 \mathrm{MH} 9)\end{array}$ & $\begin{array}{l}1: 90,000 \\
(\mathrm{CP} 3 \mathrm{PKOG})\end{array}$ \\
\hline $\begin{array}{l}\text { Vilkitski Strait } \\
\text { Severnaya Zemlya, } \\
\text { Kara Sea - Laptev Sea }\end{array}$ & No coverage & $\begin{array}{l}1: 100,000 \\
(13400,14314 \\
14315,14316)\end{array}$ & $\begin{array}{l}\text { 1:180,000 } \\
\text { (RU3PMS90, } \\
\text { RU3PLRO0) }\end{array}$ & $\begin{array}{l}1: 90,000 \\
\text { (CP3PNS80 partly), } \\
1: 200,000 \\
\text { (CP3PMS90, } \\
\text { CP3PLR00 other part) }\end{array}$ \\
\hline $\begin{array}{l}\text { Shokalski Strait } \\
\text { Severnaya Zemlya, } \\
\text { Kara Sea - Laptev Sea }\end{array}$ & No coverage & $\begin{array}{l}1: 50,000 \\
(16366,16367, \\
16368,16343), \\
1: 100,000 \\
\text { (14318 eastern } \\
\text { approach), } \\
1: 200,000 \\
\text { (12338 western } \\
\text { approach) }\end{array}$ & $\begin{array}{l}1: 180,000 \\
\text { (RU3PORG0) }\end{array}$ & $\begin{array}{l}\text { 1:45,000 } \\
\text { (CP4PQRS0, } \\
\text { CP\$PPRP0) }\end{array}$ \\
\hline $\begin{array}{l}\text { North of Severnaya } \\
\text { Zemlya }\end{array}$ & No coverage & $\begin{array}{l}1: 200,000(12336 \\
12337)\end{array}$ & $\begin{array}{l}1: 180,000 \\
\text { (RU3Q0QQ0, } \\
\text { RU3Q0RE0) } \\
\end{array}$ & $\begin{array}{l}1: 200,000 \\
\text { (CP3Q0QQ0) }\end{array}$ \\
\hline $\begin{array}{l}\text { Laptev Strait } \\
\text { New-Siberian Islands, } \\
\text { Laptev Sea - } \\
\text { East-Siberian Sea }\end{array}$ & No coverage & $\begin{array}{l}1: 100,000 \\
(13430,13455)\end{array}$ & $\begin{array}{l}\text { 1:180,000 } \\
\text { (RU3P7VS0, } \\
\text { RU3P6W90) }\end{array}$ & $\begin{array}{l}1: 200,000 \\
\text { (CP3P7VS0) }\end{array}$ \\
\hline $\begin{array}{l}\text { Sannikov Strait } \\
\text { New-Siberian Islands, } \\
\text { Laptev Sea - } \\
\text { East-Siberian Sea }\end{array}$ & No coverage & $\begin{array}{l}1: 100,000 \\
(13432,13448)\end{array}$ & $\begin{array}{l}\text { 1:180,000 } \\
\text { (RU3PCV80, } \\
\text { RU3PBVP0) }\end{array}$ & $\begin{array}{l}1: 200,000 \\
\text { (CP3PBVP0) }\end{array}$ \\
\hline $\begin{array}{l}\text { North of New-Siberian } \\
\text { Islands }\end{array}$ & No coverage & $\begin{array}{l}1: 200,000(12415, \\
12416,12417, \\
13418,12419) \\
\end{array}$ & $\begin{array}{l}1: 180,000 \\
\text { (RU3PGV80, } \\
\text { RU3PVG0) } \\
\end{array}$ & $\begin{array}{l}\text { 1:200,000 } \\
\text { (CP3PGVP0) }\end{array}$ \\
\hline $\begin{array}{l}\text { De Long Strait } \\
\text { Wrangel Island, } \\
\text { New-Siberian Islands } \\
\text { - Chukchi Sea }\end{array}$ & $\begin{array}{l}1: 5,000,000 \\
(4521)\end{array}$ & $\begin{array}{l}1: 200,000 \\
(12430,12431)\end{array}$ & $\begin{array}{l}1: 180,000 \\
\text { (RU3OOZO0, } \\
\text { RU3P0OT0) }\end{array}$ & $\begin{array}{l}1: 200,000 \\
\text { (CP30RZ60) }\end{array}$ \\
\hline $\begin{array}{l}\text { North of the Wrangel } \\
\text { Island }\end{array}$ & $\begin{array}{l}1: 27,000,000 \\
(4002)\end{array}$ & $\begin{array}{l}1: 50,000 \\
(16475,16476)\end{array}$ & $\begin{array}{l}\text { 1:180,000 } \\
\text { (RU3P0ZM0, } \\
\text { RU3P0OT0) } \\
\end{array}$ & $\begin{array}{l}1: 200,000 \\
(\mathrm{CP} 300 \mathrm{CO})\end{array}$ \\
\hline $\begin{array}{l}\text { Bering Strait } \\
\text { Chukchi Sea-Bering Sea }\end{array}$ & $\begin{array}{l}1: 1,000,000 \\
(4814)\end{array}$ & $\begin{array}{l}1: 100,000 \\
(14435,64251)\end{array}$ & \begin{tabular}{|l|}
$1: 180,000$ \\
(RU3OE090)
\end{tabular} & $\begin{array}{l}1: 25,000 \\
\text { (CP30E040) }\end{array}$ \\
\hline
\end{tabular}




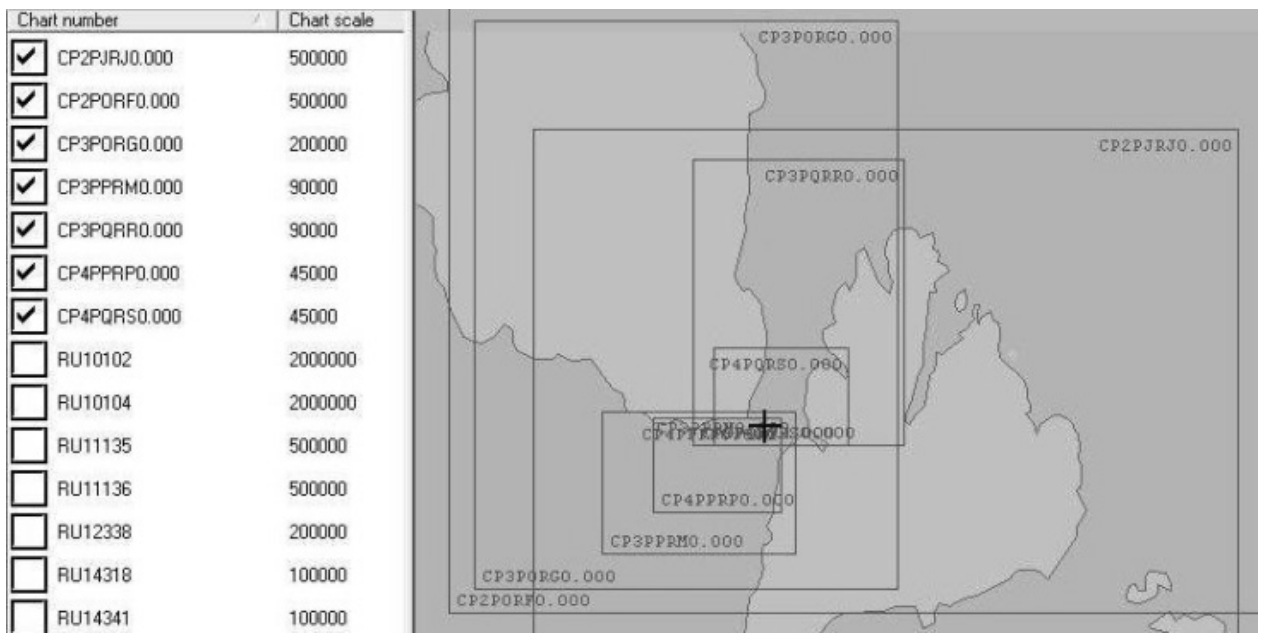

Fig. 2. Shokalski Strait region in Severnaya Zemlya archipelago; scale change proportionally to the width of passage (author's study based on ChartPilot 2010)

pages, and the National Geospatial Intelligence Agency NGIA - 952 pages). Debatable seems to be a matter of completeness of the information (Russia -5 on the 7 groups, United Kingdom Hydrographic Office UKHO - 5 on the 7 groups, the National Geospatial Intelligence Agency NGIA - 3 on the 7 thematic groups - see table 2).

Russia does not provide tide tables for the Northern Sea Route region. This information provides only the British Admiralty. It is surprising the lack a sale of a guide for planning routes on Northern Sea Route. The first such guidance was issued in Russia in 1996 in two languages (GUNiO 4151 - Руководство для сквозного плавания судов по Северному морскому пути and GUNiO 4151B - Guide to navigating through the Northern Sea Route). At present the Russians claim that the stocks of both the Russian version and the English one have been sold and are not expected to re-issue. The only available alternative to these guides are electronic versions of publications like Справочник по ледовым условиям плавания на трассах Северного Морского Пути (ESIMO 2011/1), Справочник по опасным гидрометеорологическим и ледовым явлениям на трассах Северного Морского пути (ESIMO 2011/2) and Навигационно-геогра- фрицеский очерк трассы СМП (ESIMO 2011/3) available on the Russian websites. However, these electronic versions are not official nautical publications.

\subsection{Discussion of results}

Analysis of official nautical publications available for selected thematic groups confirms the suggestions of National Geospatial Intelligence Agency (NGIA 2010/1, 2010/2) that despite available various English-language publications (eg. related to tides), the vessel's travelling through the Northern Sea Route (by default, for the route planning) should use primarily the latest available Russian publications. This involves the necessity of acquiring Russian "Notices to Mariners" in a systematic manner. This procedure can be a big problem for non-Russian shipowners.

\section{Continuation of hydrographic research}

Due to the great interest of many owners in possibility of using the Northern Sea Route for the shipping started hydrographic research work on a grand scale.

Completed hydrographic recognition in the last few years and planned for the following 
Table 2. Summary of official nautical publications offered by the main producers (United Kingdom Hydrographic Office UKHO, Chief Directorate for Navigation \& Oceanography GUNiO and the National Geospatial Intelligence Agency NGIA) for the Northern Sea Route (author's study based on the given literature)

\begin{tabular}{|c|c|c|c|}
\hline Publications & $\begin{array}{l}\text { United Kingdom } \\
\text { Hydrographic Office }\end{array}$ & $\begin{array}{l}\text { Chief Directorate for Navigation } \\
\text { \& Oceanography GUNiO / } \\
\text { Directorate for Navigation } \\
\text { \& Oceanography UNiO }\end{array}$ & $\begin{array}{l}\text { National Geospatial } \\
\text { Intelligence Agency }\end{array}$ \\
\hline $\begin{array}{l}\text { Pilots (Sailing } \\
\text { directions) }\end{array}$ & 2/688 (NP10, NP23) & $\begin{array}{l}\text { 4/1220 (GUNiO 1115, 1118, } \\
1119,1120)\end{array}$ & $\begin{array}{l}\text { 2/317 (Pub.180, } \\
\text { Pub.183) }\end{array}$ \\
\hline List of Lights & 1/290 (NP84) & 1/288 (GUNiO 2111) & $\begin{array}{l}3 / 333 \text { (Pub. } 115 \text { and } \\
\text { partly Pub. } 111 \text { i Pub. } 112 \\
\text { for Bering Strait) }\end{array}$ \\
\hline Tide Tables & $\begin{array}{l}\text { 1/344 (NP202, } \\
\text { NP204) }\end{array}$ & $\begin{array}{l}\text { No coverage. Publication is } \\
\text { available only for waters outside } \\
\text { Russia (UNiO 6003) }\end{array}$ & No coverage \\
\hline $\begin{array}{l}\text { Radio signals } \\
\text { (Electronic aids to } \\
\text { navigation) }\end{array}$ & 1/25 (NP282) & 2/548 (GUNiO 3001, 3003) & $\begin{array}{l}1 / 151 \text { as half related to } \\
\text { this subject (Pub. } 117 \text { and } \\
\text { partly Pub. } 111 \mathrm{i} \text { Pub. } 112 \\
\text { for Bering Strait) }\end{array}$ \\
\hline $\begin{array}{l}\text { Radio Signals } \\
\text { (GMDSS, Weather } \\
\text { informations, Naviga- } \\
\text { tional Warnings, } \\
\text { Navtex, SafetyNET, etc) } \\
\end{array}$ & $\begin{array}{l}\text { 2/190 (NP285, } \\
\text { NP283(1)) }\end{array}$ & 2/376 (GUNiO 3008, 3012) & $\begin{array}{l}1 / 151 \text { as half related } \\
\text { to this subject (Pub.117) }\end{array}$ \\
\hline $\begin{array}{l}\text { Distance tables be- } \\
\text { tween ports }\end{array}$ & $\begin{array}{l}1 / 1 \text { a very small } \\
\text { number of ports } \\
\text { and high generality }\end{array}$ & $\begin{array}{l}\text { 2/182 (GUNiO 9010, GUNiO } \\
\text { 9010P) }\end{array}$ & No coverage \\
\hline $\begin{array}{l}\text { Guides for voyage } \\
\text { planning like „Ocean } \\
\text { passages ....” }\end{array}$ & No coverage & $\begin{array}{l}\text { No sale for the region of Northern } \\
\text { Sea Route (GUNiO 4151, GUNiO } \\
4151 W)\end{array}$ & No coverage \\
\hline
\end{tabular}

The value before the slash is the number of related publications, and the value after the slash - the total number of pages in the publications

years, (B. Gunnarsson 2012; N. Monko 2012; Y. Melenas 2013; K. Palnikov 2013; I. Pankov 2013) leads to an ever better understanding of the seas bathymetry that are crossed by the various sections of the Northern Sea Route. This results in the appointment of more and more new variants of passage of this route which can be used for deep draft vessels. Survey works carried out in the years 2011 and 2012 in the south-eastern part of the Kara Sea (fig. 3) and to the north of the New-Siberian Islands (fig. 4) led to the appointment of several new variants of the deep-water route, recommended for the vessels with a draft of $15 \mathrm{~m}$. According to Y. Melenas (2013), the Northern Sea Route Administration is planning to hold further $205,000 \mathrm{~km}$ of survey profiles during the detailed recognition of bathymetry for the 2019 . Large-scale hydrographic works indicate that the Northern Sea Route Administration expects further intensive development of the route as a transport lane.

\section{Summary and conclusions}

Vessels can be provided with Russian official nautical charts on a scale appropriate to the kind of the navigation for selected regions of the Russian Arctic including Northern Sea Route. The other main coastal countries or producers of official nautical charts do not provide full coverage of this region or the scale of the charts is worse or even unsatisfactory. 


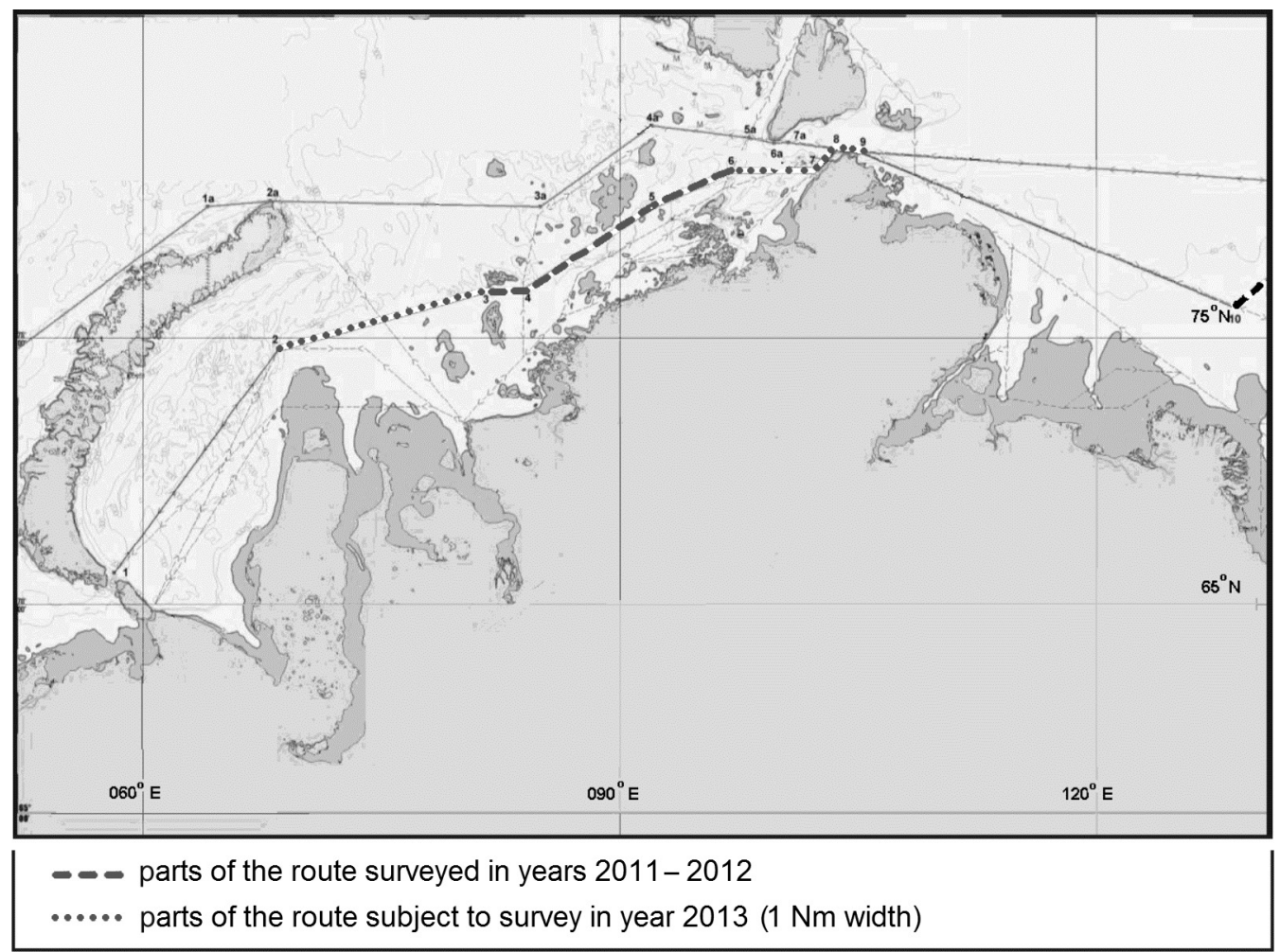

Fig. 3. Research and determining further recommended routes in the western part of the Northern Sea Route (author's study based on N. Monko 2012, Y. Melenas 2013, K. Palnikov 2013 and I. Pankov 2013)

The availability of official nautical publications supplied by global producers is more diverse and more ambiguous than it is in the case of nautical charts. It is surprising the lack of Russian publications on tides. On the basis of the information contained in the Russian sailing directions to be expected that such information can be obtained on an ongoing basis via radio communications with designated for this purpose shore station. No sales of guidance for planning routes on Northern Sea Route issued by Russia in Russian and English also requires consideration.

Global producers of the official charts and nautical publications recommend that ships use the products supplied by Russia. Because they are published in Russian, this is a serious impediment to their use and thus introduces privilege of ships' crews who speak Russian.

Research on available official nautical charts indicate a systematic improvement.
Northern Sea Route leads through regions that are not sufficiently explored. It is recommended to guide vessels only on charted routes and described in nautical publications. Hydrographic works are aimed primarily to appoint new routes according to the spatial distribution of ice massifs in a navigation season. The research focuses on narrow strips along the newly appointed routes. It is expected that limited number of research vessels are able to perform measurements in ice-covered regions that only allow updating of bathymetric data in narrow strips needed for current transit voyages on the Northern Sea Route and making compilation of inserts to the currently used charts. However, this does not solve the problem of a comprehensive exploration of the Russian Arctic regions for the implementation of safe navigation on custom routes. 


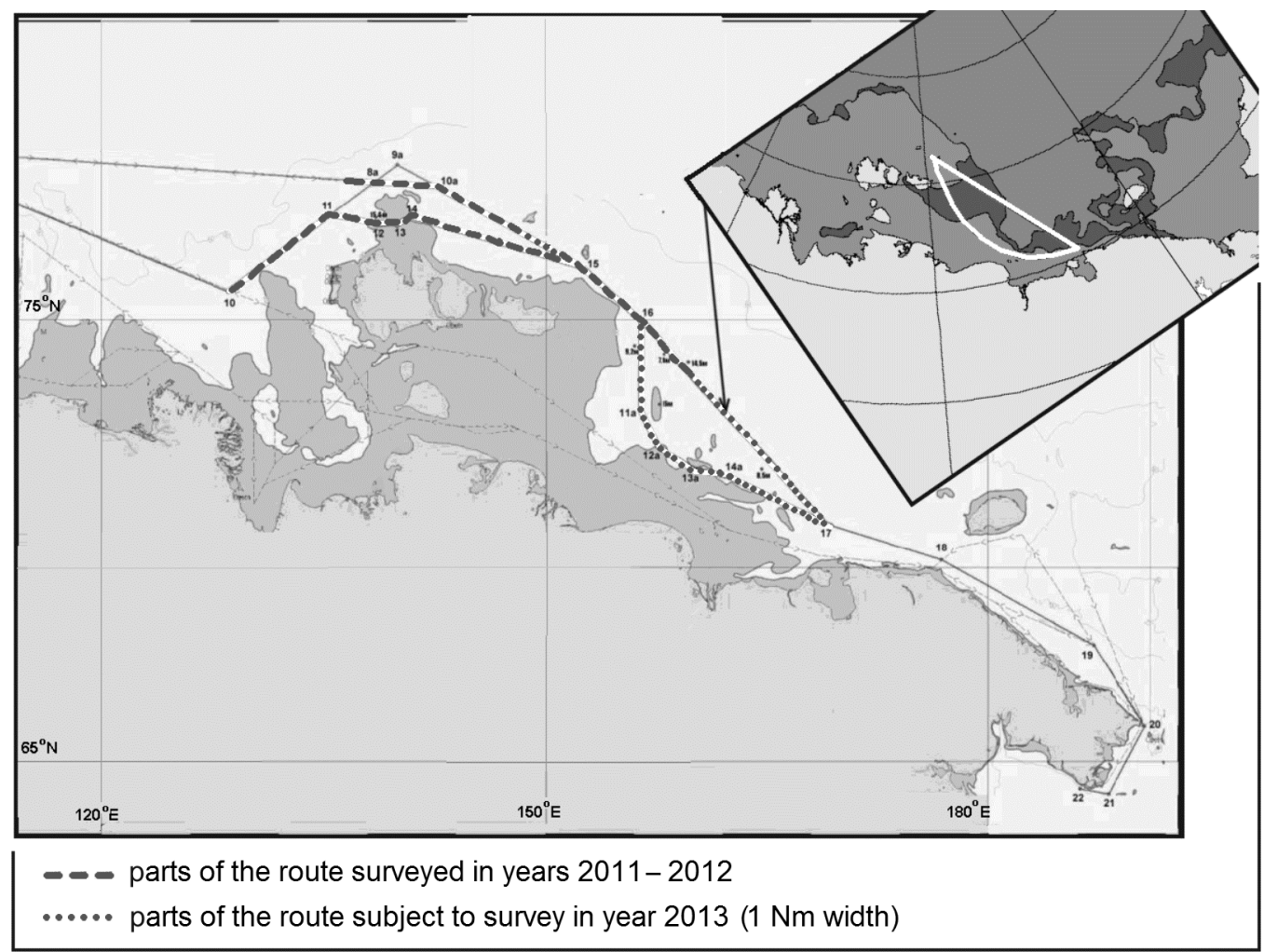

Fig. 4. Research and determining further recommended routes in the eastern part of the Northern Sea Route (author's study based on N. Monko 2012, K. Palnikov 2013 and I. Pankov 2013)

\section{References}

Armstrong T., 1952, The Northern Sea Route, Soviet exploitation of the North East Passage. Cambridge, $166 \mathrm{pp}$.

Centkiewiczowie A. \& Cz., 1959, Na podbój Arktyki. Warszawa: Państwowe Wydawnictwo Naukowe, 590 pp.

Chart Pilot, 2010, ChartPilot Order. Version 4, Offline (software).

ESIMO, 2011/1, Справочник по ледовым условиям плавания на трассах Северного Морского Пути, (http://www.aari.ru/projects/ECIMO/index.php?im $=200$, attempt 28.11.2014).

ESIMO, 2011/2, Справочник по опасным гидрометеорологическим и ледовым явлениям на mрассах Северного Морского пути (http:// www.aari.ru/projects/ECIMO/index.php?im=200, attempt 28.11.2014).

ESIMO, 2011/3, Навигационно-географицеский очерк трассы СМП, (http://www.aari.ru/projects/ ECIMO/index.php?im=200, attempt 28.11.2014).
GUNiO, 1996/1, Rukovodstvo dlja skvoznogo plavanija sudov po Severnomu morskomu puti, GUNiO MORF Nr 4151, 415 pp.

GUNiO, 1996/2, The Guide to Navigating Through the Northern Sea Route. GUNiO Nr 4151W, 412 p.

Gunnarsson B., 2012, Arctic Shipping: What will Influence the Short to Medium Term Scenarios. 5th Harsh Weather Summit 22-23 May 2012, 50 pp.

Intergovernmental Panel on Climate Changes, 2013, The final draft Report, dated 7 June 2013, of Working Group I contribution to the IPCC 5th Assessment Report "Climate Change 2013: The Physical Science Basis", Working Group I - Twelth Session, Stockholm, 23-25 September, 2216 pp. Johannessen O.M., Alexandrov V.Yu., Frolov I.Ye., Sandven S., Pettersson L.H., Bobylev L.P., Kloster K., Smirnov V.G., Mironov E.U., Babich N., 2007, Remote sensing of sea ice in the Northern Sea Route: Studies and applications. Praxis Springer, 512 pp. 
Jurdziński M., 1989, Nawigacyjne planowanie podróży. Gdańsk: Wydawnictwo Morskie, 188 pp.

Marchenko N., 2012, Russian Arctic Seas. Navigational conditions and accidents. Berlin-Heidelberg: Springer-Verlag, $293 \mathrm{pp}$.

Melenas Y., 2013, Support system for the Northern Sea Route. World Maritime Day Symposium on a Sustainable Maritime Transportation System. London, $34 \mathrm{pp}$.

Monko N., 2012, Summary of the navigation 2011, Legislation and administrative procedures regulating the navigation along the Northern Sea Route. Northern Sea Route Administration: $12 \mathrm{pp}$. http://www.chnl.no/publish_files/Nikolay_Monko. pdf (attempt: 2013-03-24).

MMM, 1990, Ministry of Merchant Marine, Rules of navigation regulations for navigation on the seaways on the Northern Sea Route. Approved by the USSR Ministry of Merchant Marine 14 September 1990), Order of the Council of Ministers of the USSR Nr 565, 6 pp.

Mulherin N.D., Sodhi D., Smallidge E., 1994, Northern Sea Route and Icebreaking Technology. An overview of current conditions. CRELL Report No 3520, US Army Corps of Engineers, 165 pp.

Mulherin N.D., 1996, The Northern Sea Route. Its development and evolving state of operations in the 1990s. CRELL Report 96-3, US Army Corps of Engineers, $84 \mathrm{pp}$.

Palnikov K., 2013, Importance of the Northern Sea Route. Importance of the Northern Sea Route (NSR) and Operational Considerations. Government \& Industry Cooperation in the Arctic, St. Petersburg Seminar, St. Petersburg (http://www. itopf.com/ news-and-events/events/documents/2_Importan-
ceoftheNorthernSea RouteNSRandOperationalConsiderations.pdf (attempt: 2013-12-20), 14 pp.

Pankov I., 2013, Operations of Sovcomflot in the Arctic. Government \& Industry Cooperation in the Arctic, St. Petersburg Seminar, St. Petersburg (http://www. itopf.com/news-and-events/events/ documents/2_ImportanceoftheNorthernSea RouteNSRandOperationalConsiderations.pdf (attempt: 2013-12-20), 43 pp.

Pastusiak T., 2009, Problemy wykorzystania elektronicznych katalogów map morskich. „Zeszyty Naukowe Akademii Morskiej w Gdyni" Nr 63, pp. 74-85.

Pastusiak T., 2011, Wybrane przypadki powstawania awarii statków morskich $w$ rejonach polarnych $w$ aspekcie niedostatecznego zabezpieczenia transportu morskiego. „Prace Wydziału Nawigacyjnego Akademii Morskiej w Gdyni” Nr 26, pp. 43-60.

Peresypkin F., Yakovlev A., 2008, The Northern Sea Route's role in the system of International Transport Corridors. Focus-North 2-2008, 6 pp.

PRIMAR, 2011, Chart Catalogue. Version 4.5 Offline, Revision 10499, 03.05.2011.

Ragner C.L., 2000, Northern Sea Route cargo flows and infrastructure - Present State and Future Potential. The Fridtjof Nansen Institute, Report 13/2000, $124 \mathrm{pp}$.

UKHO, 2011, The United Kingdom Hydrographic Office. Admiralty digital catalogue. Version 1.6.0., Built Nr. 131, 11.01.2011.

UNiO, 2011, MORF, Katalog kart i knig, Severnyj Ledovityj Okean. UNiO Nr 7107, Last correction 05.02.2011, $80 \mathrm{pp}$.

Walsh J.E., 2008, Climate of Arctic marine environment. „Ecological Applications” 18(2) Supplement, S3-S22. 